\title{
Kinetics of immune response to foot-and-mouth disease virus (type Asia 1) in experimental cattle
}

\author{
Mohan S. Maddur • Mukund R. Gajendragad • \\ Subodh Kishore • Susurla Gopalakrishna • Nem Singh
}

Published online: 6 February 2009

(C) Springer Science + Business Media B.V. 2009

\section{Erratum to: Vet Res Commun (2009) 33:103-109 DOI 10.1007/s11259-008-9076-4}

The original version of this article unfortunately contained a mistake. The name of the first author is incorrect. It should have been "Mohan S. Maddur" instead of "M. S. Mohan".

The online version of the original article can be found at http://dx.doi.org/10.1007/s11259-008-9076-4

M. S. Maddur $\cdot$ S. Kishore $\cdot$ S. Gopalakrishna

Indian Veterinary Research Institute, Bangalore, 560024 Karnataka, India

M. R. Gajendragad $(\bowtie)$

Project Directorate on Animal Disease Monitoring and Surveillance, Hebbal, Bangalore, 560024

Karnataka, India

e-mail: gajendragad@gmail.com

N. Singh

Joint Directorate of Research, Indian Veterinary Research Institute, Izatnagar 234143 UP, India 